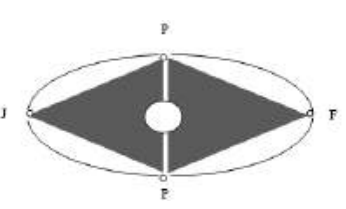

\title{
PENGEMBANGAN LKS IPA TERPADU TIPE TERHUBUNG BERBASIS ICT MENGINTEGRASIKAN NILAI KARAKTER UNTUK IMPLEMENTASI STANDAR PROSES PADA SISWA SMP KELAS VIII
}

\author{
Asrizal, Elma Rafika, and Ayu Triana \\ Jurusan Fisika FMIPA Universitas Negeri Padang, (asrizal_unp@yahoo.com)
}

\begin{abstract}
ABSTRAK
Pembelajaran IPA di SMP seharusnya dilaksanakan secara terpadu. Kenyataan menunjukkan pembelajaran IPA terpadu belum terlaksana dengan baik. Salah satu alternatif untuk mengatasi permasalahan ini adalah mengembangkan LKS IPA terpadu berbasis ICT agar siswa terlibat secara aktif dalam mengkonstruksi pengetahuan. Tujuan dari penelitian adalah untuk menyelidiki validitas dari LKS IPA terpadu, menentukan kepraktisan dan efektivitas penggunaan LKS IPA terpadu berbasis ICT dalam pembelajaran. Jenis penelitian yang dilakukan adalah penelitian dan pengembangan yaitu suatu metode penelitian yang bertujuan untuk mengembangkan suatu produk dan menguji efektivitas penerapannya. Instrumen yang digunakan untuk mengumpulkan data adalah lembar validasi, lembar kepraktisan, dan lembar tes hasil belajar. Berdasarkan analisis data dapat dikemukakan tiga hasil penelitian ini. Pertama, nilai rata-rata validasi tenaga ahli setiap komponen penilaian LKS IPA terpadu berbasis ICT bervariasi dari 84,0 sampai 88,7 dengan nilai rata-rata 85,8 yang termasuk pada kategori baik sekali. Kedua, penggunaan LKS IPA terpadu berbasis ICT adalah praktis dalam pembelajaran yang ditandai dengan penilaian guru dan siswa masing-masing 83,80 dan 86,58. Ketiga, penggunaan LKS IPA terpadu berbasis ICT adalah efektif dalam pembelajaran yang ditandai dengan peningkatan hasil belajar siswa yang signifikan pada uji coba produk dan uji coba pemakaian.
\end{abstract}

KATA KUNCI: LKS, IPA Terpadu, Tipe Terhubung, ICT

\section{PENDAHULUAN}

Era globalisasi merupakan suatu era yang penuh dengan kompetisi dan pemenangnya sangat ditentukan oleh kualitas sumber daya manusia (SDM). Dalam era ini diperlukan SDM yang memiliki keunggulan dan kemampuan untuk dapat bertahan dan berkompetisi secara sehat. Mereka harus mampu mengembangkan pengetahuan, karakter, dan keterampilannya secara profesional, serta mampu berkomunikasi dengan bang sa lain di dunia agar dapat bertahan. Dengan demikian, SDM harus memiliki kompetensi yang bagus untuk dapat eksis dalam era globalisasi.

Kehidupan dalam masyarakat telah berkembang seiring dengan perkembangan IPA dan Teknologi. Kemajuan IPA dan Teknologi menuntut manusia semakin bekerja keras untuk menyesuaikan diri dalam berbagai aspek kehidupan. Eksistensi dalam aspek pendidikan akan menentukan keberhasilan kehidupan mmanusia yang penuh tantangan dan persaingan. Proses pendidikan seharusnya mampu membentuk manusia yang menyenangi, mempelajari, dan meman faatkan IPA dan Teknologi secara utuh.

Pendidikan IPA memiliki peran penting dalam menyiapkan siswa untuk memasuki dunia kehidupan nya. Pendidikan IPA memiliki potensi besar dan peran an strategis dalam menyiapkan SDM berkualitas untuk menghadapi era globalisasi. Potensi baik ini dapat diwujudkan jika pendidikan IPA mampu melahirkan siswa yang terampil dalam bidangnya dan mampu menumbuhkan kemampuan berpikir logis, berpikir kreatif, kemampuan memecahkan masalah, bersikap kritis, menguasai teknologi, dan memiliki adaptasi terhadap perubahan dan perkembangan zaman.

Pada hakikatnya pembelajaran IPA dilakukan secara terpadu. Alasannya adalah semua fenomena alam tidak dapat dipelajari secara terpisah-pisah. IPA merupakan suatu ilmu yang mempelajari gejala-gejala alam. Alam biasanya mengenalkan dirinya sebagai satu kesatuan dan bukan terpisah-pisah. Sebagai contoh air adalah bagian dari alam yang tidak bisa hanya dilihat dari segi Fisika, Kimia, atau Biologi, tetapi merupakan kesatuan air dengan segala kandungan dan sifat-sifatya (Das S: 2009). Contoh lain adalah udara yang merupa kan bagian alam yang tidak dapat dilihat dari satu bidang ilmu saja. Udara merupakan satu kesatuan yang dapat ditinjau dari ilmu Kimia tentang kandungannya, dari ilmu Fisika tentang sifat-sifatntya, dan ilmu Biologi tentang manfaat udara dalam kehidupan makhluk hidup.

Pembelajaran terpadu adalah suatu proses pem belajaran dengan melibatkan atau mengkaitkan berba gai bidang studi (Muqoyyonah: 2010). Disisi lain pembelajaran terpadu merupakan suatu sistem pem belajaran yang memungkinkan siswa baik secara individu maupun kelompok aktif mencari, menggali, dan menemukan konsep serta prinsip keilmuwan secara holistik, bermakna, dan autentik (Trianto: 2014). 


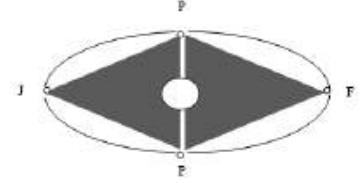

Dengan keterpaduan siswa memperoleh pengetahuan dan keterampilan secara utuh sehingga pembelajaran menjadi bermakna.

Sebagai suatu proses, pembelajaran terpadu memiliki karakteristik tertentu. Ada beberapa karak teristik pem belajaran terpadu yaitu: berpusat pada siswa, member kan pengalaman langsung kepada siswa, pemisahan antar bidang studi tidak begitu jelas, menyajikan konsep dari berbagai bidang studi dalam suatu proses pembelajaran, bersifat luwes, dan hasil pembelajaran dapat berkembang sesuai dengan minat dan kebutuhan siswa (Erna S: 2008).

Dari segi ilmu psikologi dan pendidikan, seorang siswa akan lebih mudah mengenal dan memahami benda-benda di alam secara keseluruhan terlebih dahulu dan bukan melalui bagian-bagiannya yang terkecil. Pembelajaran IPA terpadu sangat sesuai diterapkan untuk siswa SMP dibandingkan jika diberi kan secara terpisah. Pembelajaran IPA terpadu diper caya lebih mampu menumbuhkan kreativitas siswa dan lebih menyenangkan sehingga sesuai dengan tuntutan standar proses. Dengan alasan ini, pembelajaran IPA di SMP seharusnya diberikan secara terpadu sesuai dengan Permendiknas No. 22 tahun 2006. Melalui pembelajaran IPA terpadu, peserta didik dapat memper oleh pengalaman langsung, sehingga dapat menambah kekuatan untuk menerima, menyimpan, dan menerap kan konsep yang telah dipelajarinya (Muji L: 2012).

IPA terpadu adalah suatu kombinasi dari semua ilmu IPA atau beberapa bagian dari IPA. IPA terpadu merupakan IPA yang disajikan sebagai satu kesatuan yang tidak terpisahkan, artinya siswa tidak belajar ilmu Fisika, Biologi, dan Kimia secara terpisah sebagai mata pelajaran yang berdiri sendiri, melainkan semua diramu dalam kesatuan (Das S: 2009). Pendidikan IPA terpadu yang telah diterapkan di negara-negara barat, mencoba menggabungkan, memadukan dan menginteg rasikan pembelajaran IPA dalam satu kesatuan yang utuh (Zuhdan K: 2011). Mengintegrasikan IPA ke dalam disiplin lain membawa arti bagi IPA, membantu siswa memahami peran IPA di masyarakat, dan membuat IPA lebih realistis (Morgan B: 2012).

Berdasarkan hasil pengamatan peneliti pada kegiatan bimbingan teknis dan supervisi kelas di Sumatera Barat ternyata pelaksanaan pembelajaran IPA di SMP dilakukan secara terpisah-pisah. Pada umumnya kompetensi yang berhubungan dengan mate ri Biologi diajarkan oleh guru Biologi, kompetensi yang berhubungan dengan materi Fisika diajarkan oleh guru Fisika. Disisi lain kompetensi yang berhubungan dengan materi Kimia diajarkan oleh guru Fisika atau guru Biologi. Dengan cara seperti ini mata pelajaran IPA di SMP dikenal dengan IPA Fisika, IPA Biologi, dan IPA Kimia. Karena itu, praktek pembelajaran IPA di SMP masih secara terpisah-pisah.

Dari hasil studi terhadap literatur yang berhu bungan dengan IPA terpadu, kenyataan menunjukkan penerapan pembelajaran IPA terpadu di SMP meng alami berbagai kendala dan permasalahan. Pertama, sajian buku dengan label IPA terpadu masih sekedar formalitas, isi buku cenderung mengacu pada salah satu kajian IPA (L. Yulianti: 2013). Kedua, rendahnya penguasaan guru terhadap IPA terpadu sehingga pembelajaran IPA terpadu belum terlaksana (Maryati: 2012). Ketiga, kurang sesuainya kompetensi guru IPA di SMP dengan IPA terpadu (Insih W : 2011).

Dengan penerapan pembelajaran IPA secara terpisah-pisah menyebabkan penguasaan siswa terha dap IPA menjadi rendah. Fakta ini diperkuat oleh hasil studi tingkat literasi IPA siswa Indonesia berada pada peringkat ke 57 dari 65 negara peserta dengan skor yang diperoleh 383 dan skor ini berada di bawah ratarata standar dari PISA (Elsy Z : 2013). Dalam laporan hasil PISA 2012 dituliskan bahwa rata-rata nilai IPA siswa Indonesia adalah 382, dimana Indonesia menempati peringkat 64 dari 65 negara peserta. Dengan kata lain siswa Indonesia menempati peringkat kedua terbawah dari seluruh Negara peserta PISA (Feni K: 2014).

Salah satu alternatif solusi untuk mengatasi permasalahan ini adalah mengembangkan LKS IPA terpadu berbasis ICT mengintegrasikan nilai karakter untuk pembelajaran siswa SMP. Hal ini sesuai dengan rancangan perubahan kurikulum 2013 yang menyata kan bahwa kompetensi ideal dari lulusan ada tiga aspek. Pertama, lulusan suatu pendidikan harus memiliki karakter mulia. Karater ini sering disebut dengan karakter cerdas. Kedua, lulusan suatu pendidikan harus memiliki keterampilan yang relevan dengan bidangnya. Hal ini mengisyaratkan bahwa seorang lulusan pendi dikan tidak cukup hanya memiliki satu keterampilan dalam bidangnya, tetapi perlu menambah keterampilan lain yang relevan. Terakhir, lulusan suatu pendidikan perlu memiliki pengetahuan-pengetahuan terkait. Keti ga kompetensi lulusan pendidikan ini mengisyaratkan tentang pentingnya integrasi dalam membentuk kompe tensi lulusan.

Integrasi merupakan bagian penting dalam struktur kurikulum 2013 di SMP. Di SMP ICT menjadi media untuk semua mata pelajaran. Dengan dasar ini, semua mata pelajaran seharusnya memanfaatkan ICT dalam proses pembelajaran. Dengan cara ini siswa memiliki keterampilan ICT seperti mengakses sumber belajar dan memanfaatkan sumber belajar dari internet. Disamping itu, proses pembelajaran IPA dan IPS masing-masing diajarkan secara terpadu. Pendidikan IPA berorientasi aplikatif, pengembangan kemampuan berpikir, kemampuan belajar, rasa ingin tahu, dan pembangunan sikap peduli dan bertanggung jawab terhadap lingkungan alam. Dengan alasan ini maka pengembangan perangkat pembelajaran IPA terpadu berbasis ICT perlu dilakukan dalam menyongsong berlakunya kurikulum 2013.

Pemanfaatan LKS IPA terpadu berbasis ICT dengan mengintegrasikan nilai karakter memberikan keuntungan dalam pembelajaran baik bagi guru maupun siswa. Keunggulan pemanfaatan ICT dalam 


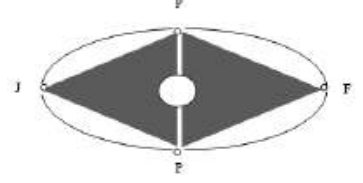

pembelajaran antara lain: memberikan kemudahan bagi guru dalam pembelajaran, mengubah peran siswa dari pasif menjadi aktif, menelaah bahan ajar sewaktuwaktu, menggunakan bahan ajar yang terstruktur dan terjadwal melalui jaringan internet, berkomunikasi secara mudah melalui fasilitas internet, dan melakukan diskusi dan berinteraksi melalui fasilitas internet secara kelompok (Ibnu F: 2010).

Dengan dasar ini peneliti tertarik untuk mengembangkan LKS IPA terpadu berbasis ICT mengintegrasikan nilai karakter yang dapat digunakan untuk mendukung pembelajaran IPA di SMP. Pengembangan LKS IPA terpadu dilakukan dengan mengintegrasikan nilai karakter dan menguji validitas, kepraktisan, dan efektivitas dari produk.

\section{METODE}

Jenis penelitian yang dilakukan adalah Research and Development (R\&D). R\&D adalah metode penelitian yang digunakan untuk menghasilkan produk tertentu, dan menguji keefektifan produk tersebut (Sugiyono: 2006). Disisi lain R\&D adalah suatu proses atau langkah-langkah untuk mengembang kan suatu produk baru atau menyempurnakan produk yang telah ada, yang dapat dipertanggung jawabkan (Nana S.S: 2006). Berarti produk merupakan bagian yang penting pada penelitian ini.

Pada kegiatan uji coba produk digunakan desain eksperimen semu dengan cara membandingkan keada an sebelum dan keadaan sesudah (before-after) diberi perlakuan. Disisi lain pada kegiatan uji coba pemakai an digunakan eksperimen semu dengan kelompok eksperimen dan kelompok kontrol.

Sebagai objek penelitian ini ada dua yaitu LKS IPA terpadu dan siswa. Kegiatan penelitian difokuskan untuk menghasilkan LKS IPA terpadu yang memiliki kriteria yang baik, valid, praktis, dan efektif. Uji coba produk dan uji coba pemakaian LKS IPA terpadu yang dihasilkan dilakukan kepada siswa SMP. Perlakuan dalam bentuk penerapan LKS IPA terpadu terpadu berbasis ICT diberikan kepada siswa dalam pembelajar an IPA di Sekolah.

Model pengembangan LKS IPA terpadu meng acu pada 10 tahap menurut Sugiono (2006). Tahap pertama adalah mengenal potensi dan masalah. Implementasi kurikulum 2013 memberikan peluang dalam pengembangan perangkat pembelajaran sains terpadu. Kurikulum 2013 mendorong adanya integrasi suatu ilmu dengan ilmu lainnya terutama di tingkat SD dan SMP, integrasi ICT kedalam suatu mata pelajaran, dan integrasi nilai karakter dalam pendidikan. Dengan adanya kompetensi inti spiritual dan kompetensi inti sosial dalam kurikulum 2013 memberikan kemudah an dalam mengintegrasikan nilai karakter kedalam LKS IPA terpadu. Dalam pengembangan LKS IPA terpadu berbasis ICT mengintegrasikan nilai karakter dihadap kan pada beberapa permasalahan. Permasalahan pertama, guru IPA di SMP terutama di Sumatera Barat belum terbiasa menerapkan pembelajaran IPA terpadu. Pembelajaran IPA selama ini masih dilakukan secara terpisah-pisah. Permasalahan kedua, masih banyak guru di SMP yang beranggapan sebagai guru Fisika dan guru Biologi. Padahal mata pelajaran yang ada di SMP adalah IPA. Permasalahan ketiga adalah implementasi kurikulum 2013 baru untuk kelas VII di SMP untuk beberapa mata pelajaran. Guru IPA SMP kelas VIII banyak yang belum bersedia menerapkan pembelajaran IPA terpadu, padahal pendekatan ini sudah dituntut dalam KTSP.

Tahap kedua adalah mengumpulkan informasi. Informasi merupakan bagian yang penting dalam mengembangkan suatu ide penelitian. Dalam pengem bangan LKS IPA terpadu berbasis ICT dengan mengintegrasikan nilai karakter ini diperoleh informasi dari diskusi dengan guru IPA SMP, supervisi pembelajaran, internet, dan kegiatan ilmiah. Dari hasil diskusi dengan guru IPA dan supervisi pembelajaran didapat beberapa informasi seperti guru sudah mulai menerapkan ICT dan karakter dalam pembelajaran. Dari referensi yang didapat di internet terutama implementasi kurikulum 2013 mendorong adanya integrasi dalam pembelajaran seperti keterkaitan dengan bidang ilmu lain, nilai karakter, dan ICT. Melaui kegiatan ilmiah seperti konasfi dan forum MIPA diperoleh informasi antara lain: pentingnya pembentukan nilai karakter bagi generasi muda melalui pendidikan, pembentukan kompetensi siswa secara utuh, relevansi kompetensi siswa dengan tuntutan era globalisasi, dan sebagainya.

Tahap ketiga adalah mendesain draf produk dalam bentuk LKS IPA terpadu. LKS IPA terpadu yang dikembangkan adalah bahan pendukung pelak sanaan pembelajaran. Struktur dari satu LKS terdiri dari: judul, petunjuk belajar, komnpetensi, materi pembelajaran, informasi pendukung, paparan isi materi, tugas atau langkah kerja, dan penilaian.

Langkah keempat adalah memvalidasi draf LKS IPA terpadu. Desain produk LKS IPA terpadu yang sudah dibuat perlu divalidasi. Tujuan uji validasi desain produk adalah untuk menilai LKS IPA terpadu efektif menurut pemikiran rasional. Penilaian validasi desain produk dilakukan oleh lima orang ahli yang menguasai pengetahuan dasar IPA, media pembelajar an, dan pemanfaatan internet sebagai sumber belajar.

Langkah kelima adalah adalah merevisi draf LKS IPA terpadu. Uji validasi desain produk LKS IPA terpadu menggunakan lembar uji validasi. Lembar uji ini disusun menggunakan kriteria penilaian bahan ajar berbasis ICT. Dalam lembar uji ini tenaga ahli memberikan penilaian, tanggapan, dan masukan. Berdasarkan tanggapan dan masukan dari tenaga ahli dilakukan perbaikan terhadap desain produk untuk menghasilkan LKS IPA terpadu yang lebih baik.

Langkah keenam dari pengembangan adalah menguji coba prototipe 2 dari LKS IPA terpadu. LKS yang yang telah direvisi diujicobakan secara terbatas. Uji coba terhadap LKS IPA terpadu menggunakan 


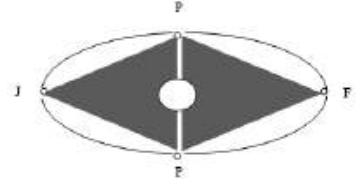

desain eksperimen sebelum dan sesudah. Sebelum pemberian perlakuan kepada siswa diberikan pretes yang dimaksudkan untuk mengetahui penguasaan siswa pada kondisi awal. Kemudian diberikan perlaku an yaitu pelaksanaan pembelajaran menggunakan LKS IPA terpadu. Pelaksanaan pembelajaran menggunakan LKS ini dilakukan untuk tiga kali pertemuan. Kegiatan selanjutnya adalah pemberian postes untuk mengetahui penguasaan siswa terhadap materi pembelajaran sete lah pemberian perlakuan.

Langkah ketujuh adalah merevisi prototipe 2 LKS IPA terpadu. Pada kegiatan uji coba terbatas ditemukan tiga kelemahan. Kelemahan pertama, masih ada tampilan pada LKS IPA terpadu yang belum baik. Kelemahan kedua, soal yang diberikan pada latihan kurang bervariasi. Kelemahan ketiga, keterbatasan jaringan internet untuk mendukung proses pembelajar an di sekolah. Berdasarkan kelemahan yang ditemukan pada waktu kegiatan uji coba produk dilakukan perbaikan. Perbaikan produk antara lain: membuat tampilan produk lebih menarik dengan menampilkan gambar yang ada di sekitar siswa dan membuat ukuran tulisan lebih besar dari sebelumnya, membuat soal yang bervariasi dalam latihan, dan mengotimalkan LKS yang dapat didownload siswa. Hasil perbaikan dari prototipe 2 disebut dengan prototipe 3 .

Langkah kedelapan adalah menguji coba pemakaian dari prototipe 3. LKS IPA terpadu yang telah diperbaiki dilakukan uji coba pemakaian. Uji coba pemakaian dilakukan pada SMP Negeri 8 Padang. Uji coba pemakaian menggunakan desain eksperimen perbading an kelompok statik dengan desain hanya kelompok kontrol. Pada satu sekolah digunakan dua kelas, satu kelas sebagai kelas eksperimen dan satu kelas lainnya sebagai kelas kontrol. Kelas eksperimen kedua adalah kelompok siswa dengan pembelajaran menggunakan LKS IPA terpadu berbasis ICT dengan mengintegrasi kan nilai karakter.

Langkah terakhir adalah merevisi prototipe 3. Dalam kegiatan uji coba pemakaian masih ditemukan beberapa kelemahan dan kendala. Dari kegiatan uji coba pemakaian ditemukan ada tiga kendala yaitu: jaringan internet pada awal kegiatan pembelajaran lambat, ada siswa yang belum mempelajari materi pembelajaran dalam LKS sebelum kegiatan pembelajar an, kesulitan siswa menggunakan LKS secara langsung pada saat kegiatan praktikum, ada sebagian kecil siswa yang tidak bisa memanfaatkan LKS di rumah karena tidak tersedia fasilitas komputer dan internet, dan rendahnya partisipasi siswa di luar jam pelajaran dalam kegiatan chatting dan forum diskusi. Berdasarkan kelemahan yang ditemukan pada kegiatan uji coba pemakaian dilakukan perbaikan antara lain: menyem purnakan dan memperkaya LKS yang dapat didown load oleh siswa, menyempurnakan LKS yang berhu bungan dengan kegiatan praktikum, dan memperkuat interaksi antara guru dengan siswa melalui kegiatan forum diskusi dan chatting. Hasil revisi dari prototipe 3 ini disebut protipe 4 .
Instrumen pengumpul data penelitian ada empat macam yaitu: lembar uji validitas, lembar uji kepraktisan, lembar observasi karakter, dan lembar tes hasil belajar. Lembar uji validitas digunakan untuk mengetahui tingkat validitas LKS IPA terpadu berbasis ICT menurut pemikiran rasional dari tenaga ahli. Lembar uji kepraktisan digunakan untuk menentukan keterlaksanaan penggunaan LKS IPA terpadu berbasis ICT dengan mengintegrasikan nilai karakter dalam pembelajaran. Sementara itu lembar tes hasil belajar digunakan untuk menentukan efektivitas penggunaan LKS IPA terpadu berbasis ICT mengintegrasikan nilai karakter dalam pembelajaran.

Ada lima macam teknik analisis produk dan data yang digunakan yaitu metoda mendeskripsikan, anali sis statistik deskriptif, metoda grafik, analisis regresi linear dan korelasi, dan analisis perbandingan berkore lasi. Metoda mendeskripsikan digunakan untuk mendes kripsikan suatu produk. Sebagai produk dalam penelitian ini adalah LKS IPA terpadu berbasis ICT mengintegrasikan nilai karakter. Analisis deksriptif digunakan untuk mengetahui informasi lebih rinci dari data hasil belajar siswa meliputi: nilai rata-rata, median, modus, simpangan deviasi, varians dan sebagainya. Metoda grafik digunakan untuk memberi kan kesan visual tentang kepraktisan penggunaan LKS IPA terpadu ICT dalam pembelajaran. Analisis regresi dan korelasi masing-masing digunakan untuk menentu kan hubungan hasil belajar sesudah dengan sebelum perlakuan dan menentukan nilai koefisien regresi. Analisis perbandingan berkorelasi digunakan untuk menentukan keefektifan penggunaan LKS IPA terpadu.

\section{HASIL}

Hasil validitas LKS ini ditentukan dari instrumen validitas tenaga ahli. Hasil validitas oleh tenaga ahli digunakan untuk menentukan kelayakan LKS dan pedoman dalam merevisi produk. Berdasarkan instru men penilaian validitas tenaga ahli terhadap LKS dianalisis empat komponen penilaian. Komponen penilaian LKS yang digunakan adalah substansi materi, desain pembelajaran, tampilan komunikasi visual, dan pemanfaatan software.

Berdasarkan analisis data instrumen penilaian penggunaan software dalam pembuatan LKS IPA terpadu dapat dikemukakan nilai setiap indikator. Nilai dari setiap indikator pemanfaatan software berkisar antara 80 sampai 92. Nilai interaktivitas menu utama dari LKS sains terpadu adalah 84. Nilai interaktivitas latihan dalam LKS sains terpadu adalah 84. Nilai interaktivitas evaluasi dalam LKS IPA terpadu adalah 88. Pemanfaatan software pendukung Ulead Video studio dan GOM player dalam LKS IPA terpadu adalah 84. Nilai pemanfaatan software pendukung macro media flash dalam LKS sains terpadu adalah 80. Nilai keaslian hasil karya tim peneliti dalam bentuk LKS IPA terpadu adalah 92. 


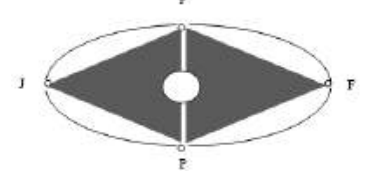

Nilai rata-rata setiap komponen penilaian vali ditas LKS IPA terpadu dapat ditentukan dari nilai setiap indikator pada komponen tersebut. Nilai ratarata dari komponen substansi materi, desain pembelajar an, tampilan komunikasi visual, dan pemanfaatan software dari LKS IPA terpadu berbasis ICT meng integrasikan nilai karakter masing-masing 84,0; 85,0; 88,7 ; dan 85,3 . Hasil plot data nilai rata-rata validitas setiap komponen dengan komponen penilaian diperli hatkan pada Gambar 1

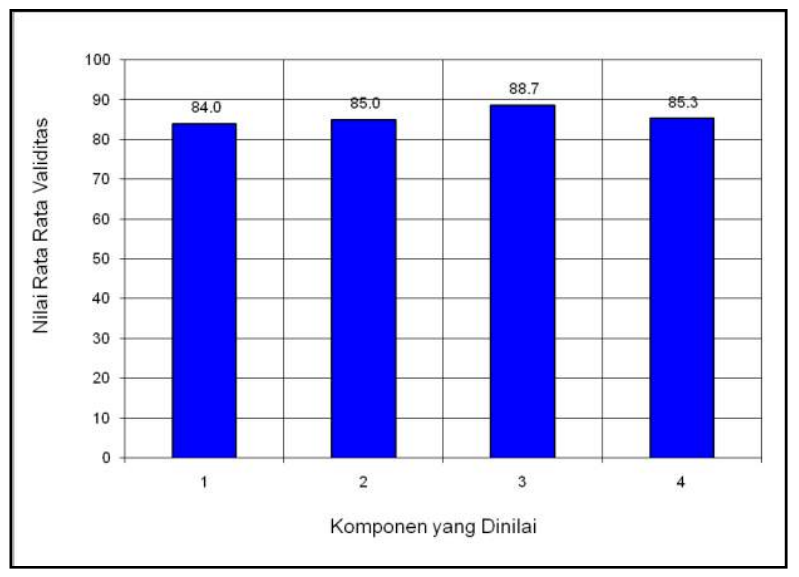

Gambar 1. Hasil Uji Validitas LKS IPA Terpadu

Dari Gambar 1 dapat dijelaskan nilai rata-rata setiap komponen penilaian pada LKS IPA terpadu. Nilai setiap komponen LKS bervariasi antara 84,0 sampai 88,7 . Nilai rata-rata validitas LKS IPA terpadu adalah 85,8. Berdasarkan nilai rata-rata ini dapat dikemukakan bahwa semua komponen LKS berada pada kategori baik sekali. Dengan demikian LKS IPA terpadu telah memiliki nilai baik sekali dengan tingkat validitas yang tinggi.

Hasil uji kepraktisan menurut guru diana lisis berdasarkan instrumen lembaran uji kepraktisan menurut guru terhadap LKS. Lembaran uji kepraktisan menurut guru terdiri dari enam komponen penilaian. Keenam komponen tersebut adalah kemudahan menggunakan menu, kemudahan panduan pengguna, penggunaan multimedia, kemudahan dalam menilai, kelebihan LKS ICT, dan peluang penggunaan dalam pembelajaran.

Berdasarkan nilai setiap komponen pada lembaran penilaian kepraktisan guru IPA dapat ditentukan rata-rata indikator pada setiap komponen penilaian. Komponen penilaian tersebut meliputi: 1) kemudahan menggunakan menu, 2) kemudahan panduan pengguna, 3) penggunaan multimedia, 4) kemudahan dalam menilai, 5) kelebihan LKS ICT, dan 6) peluang penggunaan dalam pembelajaran Hasil plot data nilai setiap komponen penilaian kepraktisan dapat dilihat pada Gambar 2:

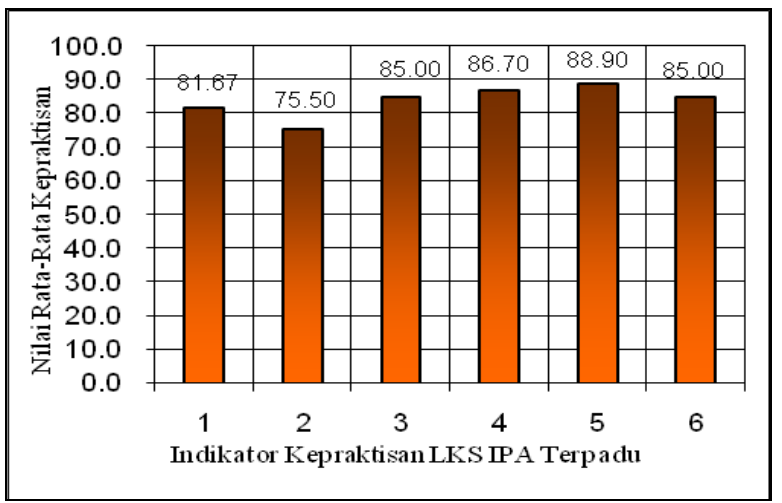

Gambar 2. Hasil Uji Kepraktisan LKS IPA Terpadu dari Guru IPA

Berdasarkan Gambar 2 dapat diungkapkan bahwa nilai kepraktisan LKS menurut guru sebagai praktisi. Secara umum lima dari enam komponen penilaian telah berada pada kategori sangat praktis. Nilai rata-rata semua komponen penilaian kepraktisan adalah 83,8. Karena itu dapat disimpulkan bahwa LKS IPA terpadu berbasis ICT dengan mengintegrasikan nilai karakter sudah berada pada kategori sangat praktis untuk digunakan dalam pembelajaran.

Berdasarkan instrumen uji kepraktisan berupa angket oleh siswa terhadap penggunaan LKS IPA terpadu berbasis ICT dengan mengintegrasikan nilai karakter dalam pembelajaran dapat diketahui kepraktis an penggunaan LKS bagi siswa. Pada instrumen uji kepraktisan oleh siswa dalam pembelajaran terdapat tujuh komponen penilaian. Ketujuh komponen penilaian itu adalah 1. kemudahan dalam penggunaan menu, 2. kemudahan panduan pengguna, 3. Pengguna an multimedia, 4. Kemudahan dalam latihan dan evaluasi, 5. Kemudahan dalam komunikasi, 6. motivasi belajar siswa, dan 7). pengaruh terhadap penguasaan materi dan penguasaan karakter.

Berdasarkan rata-rata setiap komponen dapat ditentukan rata-rata nilai kepraktisan penggunaan LKS menurut siswa. Hasil plot data nilai setiap kom ponen penilaian dapat diperhatikan pada Gambar 3:

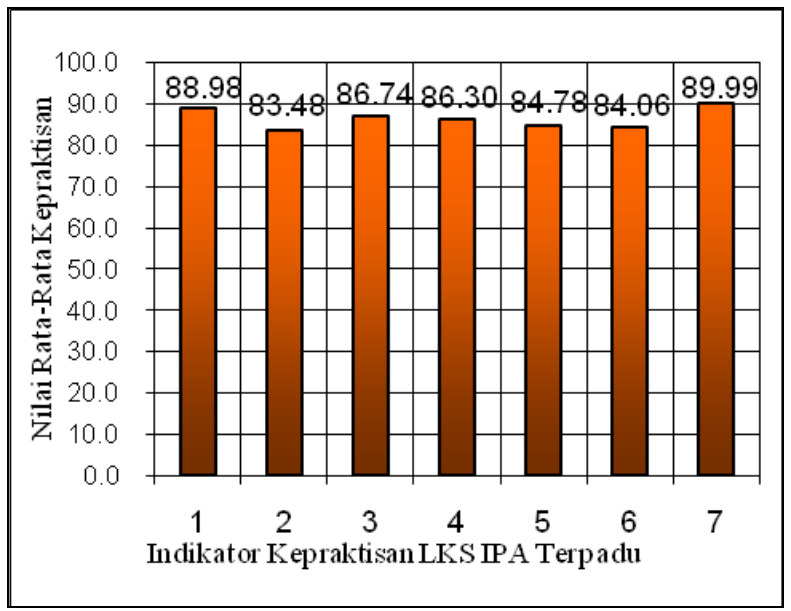

Gambar 3. Hasil Uji Kepraktisan LKS IPA Terpadu Menurut Siswa 


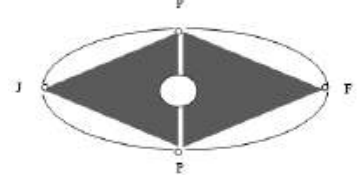

Dari Gambar 3 dapat diungkapkan bahwa nilai kepraktisan LKS IPA terpadu menurut siswa sebagai pengguna LKS dalam kegiatan pembelajaran. Nilai rata-rata dari komponen penilaian kepraktisan menurut siswa berada antara 83,48 sampai 89,99 . Nilai rata-rata terendah terletak pada komponen kemudahan panduan pengguna, sedangkan nilai rata-rata tertinggi ada pada dua komponen yaitu kemuadadahan dalam penggunaan menu dan pengaruh LKS terhadap pengetahuan dan karakter. Nilai rata-rata kepraktisan penggunaan LKS IPA terpadu adalah 86,58. Nilai rata-rata ini berada pada kategori sangat baik. Karena itu dapat disimpul kan bahwa LKS IPA terpadu berbasis ICT dengan mengintegrasikan nilai karakter praktis digunakan dalam pembelajaran.

Efektivitas penggunaan LKS IPA terpadu berbasis ICT mengintegrasikan nilai karakter ditentu kan dari hasil belajar siswa sebelum dan sesudah penggunaan LKS dalam kegiatan pembelajaran. Jumlah siswa yang mengikuti tes sebelum pengguna an LKS adalah 23 orang. Rentangan nilai siswa adalah 44,00 sampai 80,00 sehingga diperoleh jangkauan nilai sebesar 36,00. Nilai yang paling sering muncul adalah 56,00 dan nilai tengah adalah 60,00 . Nilai rata-rata tes hasil belajar awal adalah 60,17, standar deviasi adalah 9,22 dan varians adalah 85,06.

Setelah penggunaan LKS IPA terpadu berbasis ICT mengintegrasikan nilai karakter untuk tiga kali perlakuan diberikan postes kepada siswa untuk mengetahui penguasaan siswa setelah perlakuan. Analisis data hasil belajar siswa setelah perlakuan menunjukkan bahwa nilai siswa bervariasi antara 68,00 sampai 96,00 dengan rentangan nilai 28,00. Nilai yang paling sering muncul adalah 84,00 sedang kan nilai tengah adalah 84,00 . Nilai rata-rata tes hasil belajar akhir siswa sebesar 84,35 dengan varians dan standar deviasi masing- masing 43,51 dan 6,59.

Dari jumlah siswa, nilai rata-rata, nilai varian, dan nilai standar deviasi untuk postes dan pretes dapat ditentukan nilai koefisien determinasi dan nilai koefisien korelasi dari hubungan regresi linear. Dengan menggunakan software minitab didapatkan nilai koefisien determinasi dan koefisien korelasi masingmasing 0,137 dan 0,37 . Angka 0,37 berarti nilai koefisien korelasi berada pada kategori rendah.

Nilai uji perbandingan dua rata-rata ditentukan dari jumlah siswa, nilai rata-rata, nilai varians, nilai standar deviasi, dan nilai koefisien korelasi yang telah didapatkan. Dari uji perbandingan rata-rata didapatkan nilai th $=-12,53$. Disisi lain untuk derajad kebebasan 22 pada taraf kepercayaan $95 \%$ diperoleh nilai $t_{t}=1,72$.

Nilai $t_{h}$ pada penelitian lebih kecil daripada $\mathrm{t}_{\mathrm{t}}$. Dari kedua nilai $\mathrm{t}$ ini dapat dikemukakan bahwa hipotesis kerja diterima. Artinya pengguna an LKS IPA terpadu berbasis ICT mengintegrasikan nilai karakter adalah efektif digunakan dalam pembelajaran IPA di SMP kelas VIII semester 1. Hasil ini menunjukkan adanya perbedaan yang berarti antara hasil belajar sesudah dan sebelum penggunaan LKS IPA terpadu berbasis ICT mengintegrasikan nilai karakter dalam pembelajaran. Dengan demikian dapat dnyatakan bahwa LKS IPA terpadu berbasis ICT mengintegrasi kan nilai karakter efektif digunakan dalam pembelajar an menurut standar proses untuk meningkatkan hasil belajar siswa.

Pada uji coba pemakaian, pembelajaran menggu nakan LKS IPA terpadu berbasis ICT mengintegrasi kan nilai karakter dilaksanakan pada kelas ekperimen. Dalam kegiatan penelitian perlakuan diberikan delapan kali pertemuan. Setelah pemberian perlakuan kepada siswa diberikan tes hasil belajar. Data yang diperoleh dari tes akhir untuk kelas eskperimen kedua diolah menggunakan statistik deskriptif untuk menggambar kan parameter deskriptif dari hasil belajar. Pada kelas eksperimen didapatkan nilai minimum, nilai maksi mum, dan jangkauan masing-masing 62,50; 90,00; dan 27,50. Nilai rata-rata hasil belajar 76,17 , nilai median 76,25 , dan nilai yang sering muncul 80,00 . Varian dan standar deviasi dari hasil belajar kelas eksperimen masing-masing adalah 63,30 dan 7,96.

Data hasil belajar kelas eksperimen adalah terdistribusi secara normal sedangkan data hasil belajar kelas kontrol tidak terdistribusi secara normal. Sementara itu data hasil belajar kelas eksperimen dan data hasil belajar kelas kontrol memiliki varian yang sama. Dengan sifat data hasil belajar ini maka statistik yang sesuai untuk menguji hipotesis adalah Uji U Mann Whitney.

Melalui uji Mann Whitney dengan software minitab diperoleh nilai $\mathrm{P}=0,036$. Pada taraf kepercaya an 95,0 didapatkan nilai $\alpha=0,05$. Dari kedua nilai ini dapat dikemukakan bahwa nilai $\mathrm{P}$ lebih besar dari nilai $\alpha$ sehingga hipotesis Ho ditolak. Dengan kata lain hipotesis kerja diterima. Dengan demikian hasil Uji U Mann Whitney menunjukkan bahwa terdapat perbeda an hasil belajar yang berarti antara siswa dengan pembelajaran menggunakan LKS IPA terpadu berbasis ICT mengintegrasikan nilai karakter dengan siswa dengan pembelajaran tidak menggunakan LKS IPA terpadu berbasis ICT mengintegrasikan nilai karakter.

Uji perbandingan rata-rata pada kondisi awal sebelum memberikan perlakuan, siswa kelas eksperi men dan kelas kontrol memiliki kemampuan awal yang sama. Kemudian pada kelas eksperimen diberikan pembelajaran menggunakan LKS IPA terpadu berbasis ICT mengintegrasikan nilai karakter. Setelah menerap kan perlakuan ini ternyata terdapat perbedaan hasil belajar yang berarti. Adanya perbedaan hasil belajar yang berarti ini menunjukkan adanya pengaruh dari penggunaan LKS IPA terpadu. Berarti penggunaan LKS IPA terpadu berbasis ICT mengintegrasikan nilai karakter memberikan pengaruh yang berarti terhadap hasil belajar siswa kelas VIII SMP pada taraf kepercayaan 95,0. Adanya pengaruh ini memberikan isyarat bahwa penggunaan LKS IPA terpadu adalah efektif dalam pembelajaran IPA. 


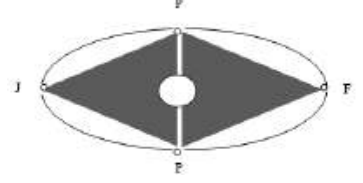

\section{PEMBAHASAN}

Melalui analisis data dapat diungkapkan hasil penelitian ini. Pada uji coba produk hasil penelitian menunjukkan bahwa penggunaan LKS IPA terpadu berbasis ICT mengintegrasikan nilai karakter adalah praktis dan efektif dalam pembelajaran menurut standar proses. Disisi lain pada uji coba pemakaian hasil penelitian menunjukkan bahwa penggunakan LKS IPA terpadu berbasis ICT mengintegrasikan nilai karakter memberikan pengaruh yang berarti terhadap hasil belajar siswa pada taraf kepercayaan 95.0.

Menurut guru sebagai praktisi dalam pembelajar an IPA di SMP penggunaan LKS IPA terpadu adalah praktis. Begitu juga menurut siswa sebagai pemakai penggunaan LKS IPA terpadu adalah praktis. Berarti guru dan siswa melihat adanya kemudahan dalam pemakaian dan manfaat dari LKS IPA terpadu berbasis ICT mengintegrasikan nilai karakter.

Pada uji coba produk terjadi peningkatan hasil belajar siswa yang berarti setelah penggunaan LKS IPA terpadu. Adanya peningkatan hasil belajar yang berarti menunjukkan bahwa penggunaan LKS IPA terpadu memberikan pengaruh yang berarti terhadap penguasaan siswa. Berarti penggunaan LKS IPA terpadu terpadu dapat digunakan untuk mencapai tujuan pembelajaran. Karena itu penggunaan LKS IPA terpadu adalah efektif dalam pembelajaran.

Pada uji pemakaian, penggunaan LKS IPA terpadu memberikan pengaruh yang berarti terhadap hasil belajar siswa. Penggunaan LKS IPA terpadu telah mengubah beberapa perilaku siswa dalam belajar. Perubahan perilaku belajar ini dapat menyebabkan perubahan hasil belajar.

Adanya kemudahan yang dirasakan oleh pemakai terhadap LKS IPA terpadu disebabkan oleh adanya kelebihan dari software moodle yang digunakan untuk membangun sistem pengelolaan pembelajaran. Pem belajaran dengan cara dapat dilakukan dimana saja dan kapan saja asalkan jaringan internet berfungsi. Disam ping itu pembelajaran ini memuat elemen multimedia sehingga lebih interaktif, menarik, dan dinamis.

Penerapan pembelajaran dengan menggunakan LKS IPA terpadu mendorong dan memfasilitasi siswa untuk belajar secara aktif. Sebelum siswa mengikuti proses pembelajaran di kelas mereka dapat mengakses sumber belajar pada LKS dan mempelajarinya. Dengan cara ini siswa diharapkan memiliki pengetahuan awal sehingga dapat berpartisipasi dengan baik dalam proses pembelajaran Dalam proses pembelajaran mereka terli bat secara aktif untuk mengkonstruksi pengetahuan dengan mengamati fenomena IPA, memikirkan feno mena IPA, memecahkan persoalan IPA, dan mengecek penguasaan terhadap materi yang telah dipelajari. Diluar jam pelajaran siswa dapat berinteraksi dengan guru melalui fasilitas chatting dan forum diskusi.

Pemanfaatan ICT dalam pembelajaran dapat mengubah peran guru dan peran siswa dalam proses pembelajaran. Dalam pembelajaran dengan ICT guru berperan sebagai fasiliator dan motivator sedangkan peran siswa adalah sebagai pembelajar aktif. Argumen ini sesuai dengan Sri A (2009) yang menyatakan bahwa dalam pembelajaran ICT siswa akan lebih dituntut aktif mencari sumber informasi yang lebih beragam, mengkomunikasikan isi informasi yang diperoleh, memunculkan pertanyaan terkait dengan isi informasi yang dipelajari, memanfaatkan lingkungan, orang-orang dan peralatan pendukung lain di sekitar nya sebagai sarana untuk belajar, merefleksikan pembelajarannya, menilai pembelajarannya, dan ber tanggungjawab atas pembelajarannya sendiri.

Argumen yang dikemukakan juga sesuai dengan Budi M (2007) yang mengemukakan bahwa kekuatan ICT telah mendorong terjadinya perubahan dalam pembelajaran. Perubahan meliputi: tujuan dan isi, aktivitas belajar, latihan dan penilaian, hasil akhir belajar, serta nilai tambah yang positif. Kekuatan ICT telah mendorong terjadinya perubahan dalam pem belajaran. Pemanfaatan ICT pada pembelajaran membe rikan banyak keuntungan, baik bagi siswa, guru, maupun pengelola pendidikan. ICT dapat memfasilitasi pembelajaran yang berpusat pada siswa, sehingga mereka dapat lebih aktif dan kreatif.

Berdasarkan hasil penelitian ini, ada beberapa rekomendasi yang disampaikan kepada siswa, guru IPA, dan pimpinan sekolah. Pertama, siswa dapat memanfaatkan LKS IPA terpadu berbasis ICT sebagai salah satu sumber belajar untuk meningkatkan keaktifan, motivasi, dan hasil belajar. Kedua, guru IPA dapat menggunakan LKS IPA terpadu ini sebagai salah satu media pendukung untuk pembelajaran siswa baik di dalam kelas maupun di luar kelas. Ketiga, pimpinan sekolah dapat mengembangkan pembelajaran berbasis ICT untuk meningkatkan kualitas pembelajaran.

Meskipun penggunaan LKS IPA terpadu berba sis ICT mengintegrasikan nilai karakter telah menunjuk kan hasil yang positif, namun dalam produk yang dihasilkan dan penerapannya dalam pembelajaran ditemukan beberapa keterbatasan dan kendala. Secara umum ada empat keterbatasan dan kendala yang dihadapi yaitu: materi pembelajaran IPA terpadu, pemecahan soal essai, jaringan internet, dan mengubah kebiasaan siswa.

Keterbatasan pertama adalah materi pembelajar an dalam LKS IPA terpadu baru untuk kelas VIII semester 1. Secara umum materi pembelajaran ini terdiri dari: gerak lurus dan penerapannya pada gerak makhluk hidup dan gerak benda dalam kehidupan sehari-hari, struktur jaringan tumbuhan dan fungsinya, sifat bahan dan pemanfaatannya dalam kehidupan sehari-hari, struktur rangka dan otot manusia, kegunaan pesawat sederhana dalam kehidupan sehari-hari, sistem pencernaan dan keterkaitannya dengan sistem yang lain dan penggunaan energi makanan, zat aditif dalam makanan dan minuman. Pengembangan LKS IPA terpadu dapat dilakukan untuk kelas SMP yang lain.

Kendala kedua adalah kesulitan dalam mengerja kan soal essay pada kotak yang tersedia terutama yang 


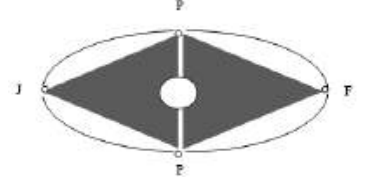

menggunakan persamaan dan gambar. Kesulitan pertama pengerjaan soal essay belum bisa memberikan umpan balik kapada siswa. Penilaian soal essay masih dilakukan secara manual oleh guru. Kesulitan kedua adalah memasukkan persamaan atau gambar ke dalam kotak yang tersedia. Upaya untuk mengatasi permasa lahan ini perlu dipikirkan.

Dalam penggunaan LKS IPA terpadu sering ditemukan kendala dalam jaringan internet. Masalah jaringan yang ditemukan antara lain: jaringan lambat dan jaringan terputus. Jika implemen tasi pembelajaran berbasis ICT ingin dikembangkan pada suatu sekolah maka jaringan internet harus mempunyai kapasitas yang besar sehingga jaringan lancar dan cepat.

Dalam penerapan pembelajaran menggunakan LKS IPA terpadu ada sebagian kecil siswa yang tidak berpartisipasi dengan baik. Sebagai contoh ada siswa yang belum mempelajari materi yang akan dibahas dalam pembelajaran, padahal materi tersebut tersedia dalam LKS. Disamping itu ada sebagian siswa yang belum berpartisipasi secara aktif dalam kegiatan chatting dan forum diskusi dengan guru, padahal kedua fasilitas ini sangat penting untuk memfasilitasi interak si antara siswa dengan guru di luar jam pembelajaran. Upaya untuk melibatkan siswa dalam kegiatan chatting dan forum diskusi perlu dipikirkan.

\section{KESIMPULAN}

Berdasarkan analisis data yang telah dilakukan pada pengembangan LKS IPA terpadu tipe terhubung dapat dikemukakan tiga hasil penelitian. Pertama, nilai rata-rata validasi setiap komponen penilaian LKS IPA terpadu berkisar dari 84,0 sampai 88,7 dng nilai ratarata 85,8 sehingga hasil validasi LKS IPA terpadu dapat dikategorikan baik sekali. Kedua, penggunaan LKS IPA terpadu berbasis ICT dalam pembelajaran adalah praktis dan efektif pada siswa SMP kelas VIII dalam uji coba terbatas. Ketiga, penggunaan LKS IPA terpadu berbasis ICT dalam uji coba pemakaian mengintegrasikan nilai karakter memberikan pengaruh yang berarti terhadap hasil belajar kognitif dan nilai karakter siswa siswa pada taraf kepercayaan 95.0.

\section{UCAPAN TERIMA KASIH}

Kegiatan penelitian ini dapat terlaksana karena bantuan dari berbagai pihak yang terkait. Dengan dasar ini peneliti mengucapkan terima kasih kepada pengambil kebijakan dalam penelitian Hibah bersaing yaitu: bapak Direktur Penelitian dan Pengabdian Masyarakat Dirjen Dikti Kementerian Pendidikan dan Kebudayaan, bapak Rektor UNP dan ketua lembaga penelitian UNP.

\section{DAFTAR PUSTAKA}

Budi Murtiyasa, (2007). Pemanfaatan Teknologi Informasi dan Komunikasi Untuk Meningkat kan Kualitas Pembelajaran Matematika. Juru Jurusan Pendidikan Matematika FKIP Univ. Muham madiyah Surakarta

Das Salirawati, (2009). Pembelajaran Terpadu Untuk Mendukung Kreativitas Siswa. Jurusan Pendidik an Kimia FMIPA UNY

Elsy Zuriyani, (2013). Literasi Sains dan Pendidikan. Kemenag Sumatera Selatan.

Erna Suwangsih, (2008). BBM 5: Pendekatan Pembelajaran Terpadu dan Model Pembelajaran Kooperatif. Universitas Pendidikan Indonesia

Feni Kurnia, dkk, (2014). Analisis Bahan Ajar SMA Kelas XI di Kecamatan Indralaya Utara Berdasarkan Kategori Literasi Sains. Jurnal Inovasi dan Pembelajaran Fisika Vol.1 No.1, Mei 2014 ISSN : 2355-7109

Ibnu Fajar, (2010). Panduan Penyusunan Bahan Ajar Berbasis TIK. Informasi Pendidikan.

Insih Wilujeng, (2011). Pengembangan Program IPA Terintegrasi Guna Membekali Kompetensi Peserta Didik Calon Guru IPA SMP. Sekolah Pascasarjana, Universitas Pendidikan Indonesia.

L. Yuliati, (2013). Efektivitas Bahan Ajar Terpadu Terhadap Kemampuan Berpikir Tingkat Tinggi Siswa SMP. Jurnal Pendidikan Fisika Indonesia 9 (2013) 53-57, ISSN: 1693-1246,

Maryati, Purwanti Widhy Hastuti, dan Eko Widodo. (2012). Tingkat Pemahaman dan Kesulitan Pelaksanaan Pembelajaran IPA Terpadu SMP/ MTS di Daerah Istimewa Yogyakarta. UNY.

Morgan B. Yarker and Soonhye Park, (2012). Analysis of Teaching Resources for Implementing an Interdisciplinary Approach in the K-12 Classroom. Eurasia Journal of Mathematics, Science \& Technology Education.

Muji Listyawati, (2012). Pengembangan Perangkat Pembelajaran IPA Terpadu di SMP. Journal of Innovative Science Education.

Muqoyyanah, A. Rusilowati, Sulhadi, (2010). Efektivitas dan Efisiensi Model Pembelajaran IPA Terpadu Tipe Integrated Dalam Pembelajar an Tema Cahaya. Jurnal Pendidikan Fisika Indonesia 6 (2010) 44-47,

Nana Syaodih Sukmadinata, (2000). Metode Penelitian Pendidikan. Program Pascasarjana Universitas Pendi dikan Indonesia dan PT Remaja Rosdakarya.

Sri Andayani (2009). Membelajarkan Organisasi Pembelajaran Dalam Pemanfaatan ICT Untuk Pembelajaran. Jurusan Pendidikan Matematika FMIPA UNY

Sugiyono, (2006). Metode Penelitian Pendidikan: Pendekatan Kuantitatif, Kualitatif, dan $R \& D$. Alfabeta, Bandung. 


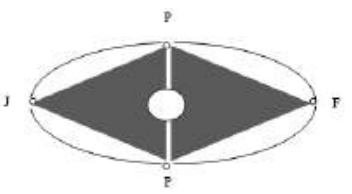

Trianto, (2014). Model Pembelajaran Terpadu: Konsep, Strategi, dan Implementasinya Dalam Kurikulum Tingkat Satuan Pendidikan (KTSP). PT Bumi Aksara, Jakarta
Zuhdan Kun Prasetyo, (2011). Pengembangan Perang kat Pembelajaran Terpadu Untuk Meningkatkan Kognitif, Keterampilan Proses, Kreativitas Serta Menerapkan Konsep Ilmiah Peserta Didik. Laporan Penelitian, Program Pascasarjana Univer sitas Negeri Yogyakarta. 